WE have investigated the serum concentrations of interleukin-6 (IL-6) and two IL-6 family cytokinesoncostatin $M$ (OSM) and leukemia inhibitory factor (LIF)-in 63 patients with B-cell chronic lymphocytic leukemia (B-CLL) and 17 healthy controls using the enzyme-linked immunosorbent assay (ELISA) method. Simultaneously, we measured the serum levels of the soluble forms of two subunits of the IL-6 receptor complex-ligand binding glycoprotein 80 $(s$ IL-6R) and glycoprotein 130 (sgp 130). The cytokines and receptors were evaluated in 25 untreated patien ts and 38 patients treated with cladribine (2-CdA), as well as in 17 healthy controls. We have correlated the serum levels of these proteins with Rai's clinical stage of the disease, the response to 2-CdA treatment and some hematological parameters. We have also evaluated the correlation of the IL-6 serum level with the concentration of OSM and IL-6 soluble receptors. IL-6 was measurable in $62 / 63(98.4 \%)$, OSM in $20 / 25(80 \%)$ of untreated and $14 / 38(37.8 \%)$ of the treated patients. sIL-6R and sgp 130 were detectable in all 63 patients and LIF in none of the CLL patients. IL-6 serum level in untreated patients was not significantly different as compared to its concentration in the control group $(P>0.05)$. However, in the patients treated with 2-CdA the IL-6 level was sign ificantly low er $(P<0.02)$, and the lowest concentration was found in the patients with complete remission (CR; median $1.4 \mathrm{pg} / \mathrm{ml} ; \boldsymbol{P}<0.02)$. The concentration of $s$ IL-6R was significantly higher in untreated (median $61.8 \mathrm{ng} / \mathrm{ml}$ ) and treated (median $50.1 \mathrm{ng} / \mathrm{ml}$ ) CLL patients when compared to normal persons (median $41.2 \mathrm{ng} / \mathrm{ml} ; P=0.04 ; P<0.001$, respectively). There was no difference between the sIL-6R levels in the patients with $C R$ and the healthy controls. In non-responders sIL-6R concentration was the highest and similar to its level in the untreated patients. OSM level was higher in the untreated patients (median $1.8 \mathrm{pg} / \mathrm{ml}$ ) than in the normal controls (median $0.0 \mathrm{pg} / \mathrm{ml} ; P<0.001$ ) and in the CR patients (median $0.0 \mathrm{pg} / \mathrm{ml} ; P<0.03$ ). The serum concentration of $s g p 130$ was similar in the untreated (median $480 \mathrm{pg} / \mathrm{ml}$ ) and treated (median $470 \mathrm{pg} / \mathrm{ml}$ ) patients, as well as in the healthy persons (median $420 \mathrm{pg} / \mathrm{ml} ; P>0.05$ ). We have found significant positive correlation between the levels of $s$ IL6R and the lymphocytes count in CLL patients $(\rho=0.423 ; P<0.001)$. In addition, sIL-6R and OSM serum concentrations correlated also with CLL Rai stage. In conclusion, the serum level of IL-6, OSM and sIL-6R, but not LIF and sgp 130, are useful indicators of CLL activity.

Key words: Chronic lymphocytic leukemia, Interleukin-6, Oncostatin M, Leukemia inhibitory factor, Soluble interleukin-6 receptor, gp 130, 2-CdA

\section{Serum levels of IL-6 type cytokines and soluble IL- 6 receptors in active B-cell chronic lymphocytic leukemia and in cladribine induced remission}

\author{
T. Robak ${ }^{\text {A A }, ~ A . ~ W i e r z b o w s k a, ~}$ \\ M. Błasińska-Morawiec, A. Korycka and \\ J. Z. Błoński
}

Department of Hematology, Medical University of Łódź, Copernicus Hospital, Pabianicka 62, 93-513 Łódź, Poland

\footnotetext{
${ }^{\mathrm{CA}}$ Corresponding Author Tel: +(4842) 6846890 Fax: +(4842) 6846890 Email: robaktad@psk2.am.lodz.pl
}

\section{Introduction}

B-cell chronic lymphocytic leukemia (CLL) is the most common leukemia in the Western world, characterized by the clonal proliferation and accumulation of $B$ lymphocytes. ${ }^{1,2}$ These leukemic lymphocytes are characterized by the expression of CD5 marker and low density monoclonal membrane immunoglobulin (Ig).

Interleukin 2 (IL-2) and its receptors have been shown to play a central role in the mechanism 
controlling the grow th of neoplastic B cells. ${ }^{3,4}$ However, leukemic cells in this disorder have also been observed to express several other cytokine receptors, including tumor necrosis factors (TNF), ${ }^{5}$ colony stimulating factors $(\mathrm{CSF})^{3}$ and interleukin-10 receptors. ${ }^{6}$

On the other hand, the leukemic cells in B-CLL can themselves express and secrete some cytokines including proinflammatory cytokines, such as TNF $\boldsymbol{\alpha}^{7,8}$ and interleukin-6 (IL-6). ${ }^{7,9}$ IL-6 is of special interest in B-CLL, because this cytokine acts as a B-cell stimulatory factor (BSF-II), mediates B-cell differentiation and can stimulate the grow th of B-cell lymphoid malignancies such as myeloma. ${ }^{10}$ In contrast, it has been proven that IL-6 is also able to inhibit TNF- $\alpha$ induced proliferation of B-cells from CLL patients. ${ }^{11,12}$

IL-6 is a member of a family of cytokines which also includes leukemia inhibitory factor (LIF), oncostatin M (OSM), ciliary neurotrophic factor (CNTF) and interleukin 11 (IL-11). ${ }^{13,14}$ These cytokines are a group of evolutionary related proteins characterized by a common tertiary framework with a distinctive four helix bundle topology. ${ }^{15,16}$

IL-6 related cytokines have also a gp130 receptor component involved in the signal transduction across the cell membrane, which explains the functional pleiotropy and redundancy of IL-6 type cytokines. ${ }^{16} \mathrm{~A}$ consequence could be the involvement of these four cytokines, in a similar way to IL-6, in numerous diseases including cancer, infections and autoimmune diseases. ${ }^{13}$

The cellular IL-6 receptor complex consists of two different proteins [an $80-\mathrm{kDa}$ ligand binding glycoprote in (IL-6R) and gp 130] and is involved in cellular signal transduction. ${ }^{17,18}$ These two subunits of the IL6R complex are proteolytically cleaved and released from the cell as soluble receptor proteins. ${ }^{19,20}$ Soluble forms of the IL-6R (sIL-6R) and gp130 (sgp 130) have been found in different body fluids in patients with various inflammatory and neoplastic diseases..$^{21,22}$

In the present study we have measured the serum concentration of IL-6, LIF, OSM, as well as sIL-6R and sgp130, in patients with active B-CLL and in patients with cladribine (2-chlorodeoxyadenosine; 2-CdA) induced remission. We have correlated the serum levels of these proteins with the clinical stage of disease according to Rai's staging system, and some hematological parameters. We have also evaluated the correlation between the serum levels of IL- 6 with both OSM and IL-6 soluble receptors.

\section{Patients and methods}

\section{Patients}

The study comprised 63 patients ( 31 females and 32 males). Their mean age was 62.4 years (range 41-81 years). The characteristics of the patients are show $n$

Table 1. Clinical and laboratory characteristics of the patients with CLL

\begin{tabular}{|c|c|c|c|}
\hline Patients' characteristics & $\begin{array}{l}\text { Untreated } \\
\text { patients }\end{array}$ & $\begin{array}{l}\text { Patients treated } \\
\text { with 2-CdA }\end{array}$ & Total \\
\hline Total & 25 & 38 & 63 \\
\hline $\begin{array}{l}\text { Age } \\
\text { Range }\end{array}$ & $\begin{array}{c}62.0 \pm 8.9 \\
47-81\end{array}$ & $\begin{array}{c}62.9 \pm 9.7 \\
41-81\end{array}$ & $\begin{array}{c}62.6 \pm 9.23 \\
41-81\end{array}$ \\
\hline $\begin{array}{l}\text { Sex } \\
\text { Male } \\
\text { Female }\end{array}$ & $\begin{array}{l}12(48 \%) \\
13(52 \%)\end{array}$ & $\begin{array}{l}20(52.6 \%) \\
18(47.4 \%)\end{array}$ & $\begin{array}{l}32(50.8 \%) \\
31(49.2 \%)\end{array}$ \\
\hline $\begin{array}{l}\text { Rai stage during analysis } \\
0 \\
1 \& 2 \\
3 \& 4\end{array}$ & $\begin{array}{l}3(12 \%) \\
16(64 \%) \\
6(24 \%)\end{array}$ & $\begin{array}{c}6(15.8 \%) \\
11(28.9 \%) \\
14(36.8 \%)\end{array}$ & $\begin{array}{c}9(14.3 \%) \\
27(42.9 \%) \\
20(31.7 \%)\end{array}$ \\
\hline Patients in CR & - & $7(18.5 \%)$ & $7(11.1 \%)$ \\
\hline Patients without residual disease & - & $4(10.5 \%)$ & $4(6.3 \%)$ \\
\hline $\begin{array}{l}\text { Hb concentration }(\mathrm{g} / \mathrm{dl}) \\
\text { Mean } \pm \mathrm{SD} \\
\text { Range }\end{array}$ & $\begin{array}{l}12.3 \pm 2.0 \\
8.3-16.2\end{array}$ & $\begin{array}{l}12.4 \pm 2.1 \\
7.0-16.5\end{array}$ & $\begin{array}{l}12.4 \pm 2.1 \\
7.0-16.5\end{array}$ \\
\hline $\begin{array}{l}\text { White blood cells }\left(\times 10^{9} / \mathrm{l}\right) \\
\text { Mean } \pm \text { SD } \\
\text { Range }\end{array}$ & $\begin{array}{c}95.6 \pm 72.6 \\
20.09-310.0\end{array}$ & $\begin{array}{c}25.9 \pm 39.8 \\
1.74-210.0\end{array}$ & $\begin{array}{l}51.5 \pm 63.3 \\
1.74-310.0\end{array}$ \\
\hline $\begin{array}{l}\text { Lymphocytes }\left(10^{9} / /\right) \\
\text { Mean } \pm \text { SD } \\
\text { Range }\end{array}$ & $\begin{array}{c}79.8 \pm 56.9 \\
13.26-283.2\end{array}$ & $\begin{array}{c}21.8 \pm 37.8 \\
0.12-199.5\end{array}$ & $\begin{array}{l}42.9 \pm 53.1 \\
0.1-283.1\end{array}$ \\
\hline $\begin{array}{l}\text { Platelets (109/l) } \\
\text { Mean } \pm \text { SD } \\
\text { Range }\end{array}$ & $\begin{array}{l}159.7 \pm 53.2 \\
30.0-272.0\end{array}$ & $\begin{array}{l}121.9 \pm 43.1 \\
26.0-208.0\end{array}$ & $\begin{array}{l}135.3 \pm 50.9 \\
26.0-272.0\end{array}$ \\
\hline
\end{tabular}


in Table 1. All the patients fulfilled the National Cancer Institute sponsored Working Group diagnostic criteria for CLL. ${ }^{23}$ At diagnosis they had peripheral lymphocytosis greater than $10 \times 10^{9} / 1$ and more than $30 \%$ lymphocytes in normal to hypercellular bone marrow. Immunologically all the patients were CD5, CD19, CD20 and CD23 positive and showed monoclonality for light chain immunoglobulin membrane surface receptors. Twenty-five patients were previously untreated and 38 had been previously treated with 2-CdA, with or without prednisone. The treatment method has been described elsewhere. ${ }^{24}$ However, none of the patients had been treated for at least 4 weeks before the measurement of cytokines.

The clinical stage of the disease according to the Rai's classification ${ }^{25}$ was determined at the time of the blood sample collection for cytokine determination. Guidelines for response in the previously treated patients were those developed by the NCI sponsored Working Group. ${ }^{23}$ Complete response (CR) required the absence of symptoms and organomegaly, and a normal complete blood cell count (absolute neutrophil count $>1 \times 10^{9} / 1$ and bone marrow with less than $30 \%$ of lymphocytes for at least 2 months). Residual disease was evaluated in CR patients by immunophenotyping of peripheral blood and bone marrow. We have used a simultaneous dual color staining flow cytometry. Blood was collected in vacuum tubes with EDTA as anticoagulant. Bone marrow cells were aspirated from the dorsal iliac crest and immediately put into heparinized tubes. ${ }^{26}$ Flow cytometry analysis was performed by EPICS-XL (Coulter, Hialeah, FL, USA). A combination of iso- thiocyanate (FITC) conjugated monoclonal antibodies was used. Residual disease was determined by the coexpression of CD5/CD19 and CD5/CD20 on B lymphocytes in conjunction with monoclonality of surface light-chain expression on CD5 positive B cells. The presence of more than $10 \%$ of the total lymphocytic population coexpressing CD19/CD5 and CD20/CD5 with monotypic light chain expression was considered as monotypic light chain expression. ${ }^{26}$

\section{Serum sampling and cytokine determination}

Venous blood samples were collected in pyrogen free tubes, allowed to clot at $-4^{\circ} \mathrm{C}$ for $1 \mathrm{~h}$ and centrifuged at $2000 \mathrm{~g}$ for $10 \mathrm{~min}$. The serum obtained was divided into aliquots and stored at $-70^{\circ} \mathrm{C}$ until assayed for IL6, OSM, LIF, sIL-6R ang gp130. The sera were randomly coded and the testing was carried out without the knowledge of the clinical status of the subject or their related laboratory data. The cytokine serum concentration was assayed by specific, commercially available, enzyme linked assay (ELISA) kits (Quantikine, R\&D Systems Inc, USA) in accordance with the manufacturer's instructions and analyzed with an ELISA reader at $492 \mathrm{~mm}$. The procedure has been described in details elsew here. ${ }^{27,29}$ The sensitivity of the assay for IL- 6 was $0.7 \mathrm{pg} / \mathrm{ml}$; for LIF $2.0 \mathrm{pg} /$ $\mathrm{ml}$ and for OSM $2.1 \mathrm{pg} / \mathrm{ml}$. Serum for SIL-6R concentration measurement was diluted 40 times and its level was measured between 7.8 and $500 \mathrm{pg} / \mathrm{ml}$. The minimum detectable dose of gp130 was less than $0.05 \mathrm{ng} / \mathrm{ml}$.

Table 2. Serum levels of IL-6, OSM, sIL-6R and sgp130 in untreated patients with CLL, patients treated with 2-CdA and normal control group. Median and range in parentheses

\begin{tabular}{|c|c|c|c|c|c|}
\hline Cytokines and receptors & $\begin{array}{c}\text { All } \\
\text { patients } \\
(n=63) \\
\text { (a) }\end{array}$ & $\begin{array}{l}\text { Untreated } \\
\text { patients } \\
(n=25) \\
\text { (b) }\end{array}$ & $\begin{array}{l}\text { Patients } \\
\text { treated } \\
\text { with } 2-\mathrm{CdA} \\
(n=38) \\
\text { (c) }\end{array}$ & $\begin{array}{l}\text { Control } \\
\text { group } \\
(n=17) \\
\text { (d) }\end{array}$ & $\begin{array}{c}\text { Statistical } \\
\text { analysis }\end{array}$ \\
\hline $\begin{array}{l}\text { IL-6 }(\mathrm{pg} / \mathrm{ml}) \\
\text { Median } \\
\text { Range }\end{array}$ & $\begin{array}{c}\mathrm{n}_{1}=62 \\
2.3 \\
0.0-66.7\end{array}$ & $\begin{array}{c}\mathrm{n}_{1}=25 \\
2.2 \\
0.8-66.7\end{array}$ & $\begin{array}{c}\mathrm{n}_{1}=37 \\
2.25 \\
0-34.4\end{array}$ & $\begin{array}{c}\mathrm{n}_{1}=17 \\
6.3 \\
0.5-14.6\end{array}$ & $\begin{array}{l}\text { a\&d } P<0.02 * \\
\text { b\&d N.S. } \\
\text { c\&d } P<0.02 * \\
\text { b\&c } P<0.02 *\end{array}$ \\
\hline $\begin{array}{l}\text { OSM (pg/ml) } \\
\text { Median } \\
\text { Range }\end{array}$ & $\begin{array}{c}\mathrm{n}_{1}=37 \\
0.45 \\
0.0-22.5\end{array}$ & $\begin{array}{c}\mathrm{n}_{1}=20 \\
1.8 \\
0-22.5\end{array}$ & $\begin{array}{c}\mathrm{n}_{1}=14 \\
0.0 \\
0-12.8\end{array}$ & $\begin{array}{c}\mathrm{n}_{1}=1 \\
0.0 \\
0-1.1\end{array}$ & $\begin{array}{c}\text { a\&d } P<0.002^{*} \\
\text { b\&d } P<0.001^{*} \\
\text { c\&d N.S. } \\
\text { b\&c N.S. }\end{array}$ \\
\hline $\begin{array}{l}\text { slL-6R (ng/ml) } \\
\text { Median } \\
\text { Range }\end{array}$ & $\begin{array}{c}\mathrm{n}_{1}=63 \\
53.18 \\
33.8-101.67\end{array}$ & $\begin{array}{c}\mathrm{n}_{1}=25 \\
61.8 \\
33.8-101.67\end{array}$ & $\begin{array}{c}\mathrm{n}_{1}=37 \\
50.1 \\
34.7-103.8\end{array}$ & $\begin{array}{c}\mathrm{n}_{1}=17 \\
41.2 \\
23.7-64.5\end{array}$ & $\begin{array}{l}\text { a\&d } P<0.004^{*} \\
\text { b\&d } P<0.001^{*} \\
\text { c\&d } P=0.04^{*} \\
\text { b\&c } P=0.04^{*}\end{array}$ \\
\hline $\begin{array}{l}\operatorname{sgp} 130(\mathrm{pg} / \mathrm{ml}) \\
\text { Median } \\
\text { Range }\end{array}$ & $\begin{array}{c}\mathrm{n}_{1}=63 \\
460 \\
310-970\end{array}$ & $\begin{array}{c}\mathrm{n}_{1}=25 \\
480 \\
310-730\end{array}$ & $\begin{array}{c}\mathrm{n}_{1}=37 \\
470 \\
330-970\end{array}$ & $\begin{array}{c}\mathrm{n}_{1}=17 \\
420 \\
310-710\end{array}$ & $\begin{array}{l}\text { a\&d N.S. } \\
\text { b\&d N.S. } \\
\text { c\&d N.S. } \\
\text { b\&c N.S. }\end{array}$ \\
\hline
\end{tabular}

*Statistically significant difference; $n=$ number of investigated patients; $\mathrm{n}_{1}=$ number of individuals with detectable cytokines; N.S., nonsignificant difference. 


\section{Statistical analysis}

The mean values were compared in Mann-Whitney $U$ test and Kruskal-Wallis test. Statistical analysis for the frequency of detectable cytokines was performed using Chi-squared test. Zero values, indicating undetectable levels, were included in all the analyses. The linear correlations between serum interleukin levels, as compared with the lymphocyte number, were evaluated using the Sperman rank-sum correlation coefficient and linear regression with the least squares method. The comparison and correlation were considered significant when $P<0.05$.

\section{Results}

The results of the measurement of IL-6, OSM, LIF, sIL6R and sgp130 in untreated patients and patients treated with 2-CdA are shown in Table 2. IL-6 was measurable in $37 / 38$ (97.4\%) treated patients, in all 25 untreated patients and in all normal individuals. sIL-6R and sgp130 were detectable in all the patients and in all the healthy controls. In contrast, OSM was measurable in $20 / 25(80 \%)$ of the untreated CLL patients, in 14/38 (37.8\%) of the treated patients and only in $1 / 17(5.9 \%)$ of the healthy persons. Because LIF was not detectable in any of the CLL patients, as well as in any person from the control group, we did not carry out any statistical analysis for this cytokine.

In our study the IL-6 serum level in CLL patients (median $2.3 \mathrm{pg} / \mathrm{ml}$ ) was significantly lower than in the healthy controls (median $6.3 \mathrm{pg} / \mathrm{ml} ; \quad P<0.02$ ). The lowest concentration of this cytokine has been found in CR (median $1.4 \mathrm{pg} / \mathrm{ml} ; P<0.002$; Table 3 ). How ever, the level of IL-6 in the untreated patients was not significantly different as compared to its concentration in the control group.

The serum OSM level was significantly higher in the CLL patients (median $0.45 \mathrm{pg} / \mathrm{ml}$ ), when compared with the normal individuals (median $0.0 \mathrm{pg} / \mathrm{ml}$; $P<0.002)$. Moreover, it was at its highest level in the untreated CLL patients (median $1.8 \mathrm{pg} / \mathrm{ml}$ ). In contrast, there was no significant difference between OSM levels in the patients with CR and the control group $(P>0.05)$.

The serum concentration of sIL-6R w as significantly higher in the untreated (median $61.8 \mathrm{ng} / \mathrm{ml}$ ) and treated (median $50.1 \mathrm{ng} / \mathrm{ml}$ ) CLL patients when compared to normal persons (median $41.2 \mathrm{ng} / \mathrm{ml}$; $P<0.001$ and $P=0.04$, respectively). There was no difference between the serum sIL-6R level in the patients with CR and the healthy control group $(P<0.05)$. Moreover, in patients who did not respond to 2-CdA treatment, the sIL-6R concentration was higher than in the responding patients, and similar to its level in the untreated group $(P>0.05)$.

The serum concentration of $\operatorname{sgp} 130$ was similar in the untreated (median $480 \mathrm{pg} / \mathrm{ml}$ ) and treated (median $470 \mathrm{pg} / \mathrm{ml}$ ) patients as well as in the healthy persons (median $420 \mathrm{pg} / \mathrm{ml}$ ). No correlation between the level of these soluble receptor and the response to treatment was found.

Table 3. Serum levels of IL-6, OSM, sIL-6R and sgp 130 in patients with CLL according to treatment response. Median and range in parentheses

\begin{tabular}{|c|c|c|c|c|c|c|}
\hline Cytokines and receptors & $\begin{array}{l}\text { Untreated } \\
\text { patients } \\
(n=25) \\
\text { (a) }\end{array}$ & $\begin{array}{l}\text { Patients } \\
\text { with CR } \\
(n=7) \\
\text { (b) }\end{array}$ & $\begin{array}{l}\text { Patients } \\
\text { with PR } \\
\text { ( } n=18) \\
\text { (c) }\end{array}$ & $\begin{array}{l}\text { Non-responded } \\
\text { patients } \\
(n=13) \\
\text { (d) }\end{array}$ & $\begin{array}{l}\text { Control } \\
\text { group } \\
(n=17) \\
(\mathrm{e})\end{array}$ & $\begin{array}{l}\text { Statistically } \\
\text { significant } \\
\text { comparisons }\end{array}$ \\
\hline $\begin{array}{l}\text { IL-6 (pg/ml) } \\
\text { Median } \\
\text { Range }\end{array}$ & $\begin{array}{c}\mathrm{n}_{1}=25 \\
2.2 \\
0.8-66.7\end{array}$ & $\begin{array}{c}\mathrm{n}_{1}=7 \\
1.4 \\
1.0-2.5\end{array}$ & $\begin{array}{c}\mathrm{n}_{1}=17 \\
2.65 \\
0-24.5\end{array}$ & $\begin{array}{c}\mathrm{n}_{1}=13 \\
2.8 \\
0-34.4\end{array}$ & $\begin{array}{c}\mathrm{n}_{1}=17 \\
6.3 \\
0.5-14.6\end{array}$ & $\begin{array}{l}\text { a-e } P=0.05 \\
\text { b\&e } P<0.02^{*}\end{array}$ \\
\hline $\begin{array}{l}\text { OSM }(\mathrm{pg} / \mathrm{ml}) \\
\text { Median } \\
\text { Range }\end{array}$ & $\begin{array}{c}\mathrm{n}_{1}=20 \\
1.8 \\
0-22.5\end{array}$ & $\begin{array}{c}\mathrm{n}_{1}=2 \\
0 \\
0-1.2\end{array}$ & $\begin{array}{c}\mathrm{n}_{1}=6 \\
0 \\
0-12.8\end{array}$ & $\begin{array}{c}\mathrm{n}_{1}=6 \\
0 \\
0-3.0\end{array}$ & $\begin{array}{c}\mathrm{n}_{1}=1 \\
0 \\
0-1.1\end{array}$ & $\begin{array}{c}\text { a-e } P=0.0001^{*} \\
\text { a\&b } P<0.03^{*} \\
\text { a\&c } P<0.004^{*} \\
\text { a\&d } P<0.004^{*} \\
\text { a\&e } P<0.001^{*}\end{array}$ \\
\hline $\begin{array}{l}\text { slL-R (ng/ml) } \\
\text { Median } \\
\text { Range }\end{array}$ & $\begin{array}{c}\mathrm{n}_{1}=25 \\
61.8 \\
33.8-101.7\end{array}$ & $\begin{array}{c}\mathrm{n}_{1}=7 \\
37.5 \\
35.9-40.6\end{array}$ & $\begin{array}{c}\mathrm{n}_{1}=18 \\
50.6 \\
34.7-107.3\end{array}$ & $\begin{array}{c}\mathrm{n}_{1}=13 \\
74.2 \\
41.8-103.8\end{array}$ & $\begin{array}{c}\mathrm{n}_{1}=17 \\
41.2 \\
23.7-64.5\end{array}$ & $\begin{array}{l}\text { a-e } P<0.001^{*} \\
\text { a\&b } P<0.001^{*} \\
\text { a\&c } P<0.05^{*} \\
\text { a\&e } P<0.001^{*} \\
\text { b\&c } P<0.005^{*} \\
\text { b\&d } P<0.001^{*} \\
\text { c\&d } P<0.05^{*} \\
\text { c\&e } P<0.05^{*} \\
\text { d\&e } P<0.001^{*}\end{array}$ \\
\hline $\begin{array}{l}\text { sgp130 (pg/ml) } \\
\text { Median } \\
\text { Range }\end{array}$ & $\begin{array}{c}\mathrm{n}_{1}=25 \\
480 \\
310-730\end{array}$ & $\begin{array}{c}\mathrm{n}_{1}=7 \\
490 \\
330-550\end{array}$ & $\begin{array}{c}\mathrm{n}_{1}=18 \\
415 \\
350-970\end{array}$ & $\begin{array}{c}\mathrm{n}_{1}=13 \\
510 \\
340-740\end{array}$ & $\begin{array}{c}\mathrm{n}_{1}=17 \\
420 \\
310-710\end{array}$ & a-e $P<0.05^{*}$ \\
\hline
\end{tabular}

*Statistically significant difference; $n=$ number of investigated patients; $n_{1}=$ number of individuals with detectable cytokines. 
Table 4. Serum levels of IL-6, OSM, sIL-6R and sgp130 in patients with CLL by Rai stage and in normal control group. Median and range in parentheses.

\begin{tabular}{|c|c|c|c|c|c|c|c|c|}
\hline $\begin{array}{l}\text { Group } \\
\text { cytokines }\end{array}$ & $\begin{array}{c}\text { All } \\
\text { patients } \\
(n=63) \\
\text { (a) }\end{array}$ & $\begin{array}{c}\text { CR } \\
(n=7) \\
(b)\end{array}$ & $\begin{array}{c}\text { Rai }=0 \\
(n=9) \\
\text { (c) }\end{array}$ & $\begin{array}{c}\mathrm{Rai}=1 \& 2 \\
(n=25) \\
(\mathrm{d})\end{array}$ & $\begin{array}{c}\mathrm{Rai}=3 \& 4 \\
(n=20) \\
(\mathrm{e})\end{array}$ & $\begin{array}{l}\text { Control } \\
\text { group } \\
(n=17) \\
(f)\end{array}$ & $\begin{array}{l}\text { Statistical } \\
\text { analysis for } \\
\text { means }\end{array}$ & $\begin{array}{l}\text { Statistical } \\
\text { analysis for } \\
\text { frequency of } \\
\text { detectable } \\
\text { cytokines }\end{array}$ \\
\hline
\end{tabular}

\begin{tabular}{|c|c|c|c|c|c|c|c|c|}
\hline $\begin{array}{l}\text { IL-6 }(\mathrm{pg} / \mathrm{ml}) \\
\text { Median } \\
\text { Range }\end{array}$ & $\begin{array}{c}\mathrm{n}_{1}=62 \\
2.3 \\
0.0-66.7\end{array}$ & $\begin{array}{c}\mathrm{n}_{1}=7 \\
1.4 \\
1.0-2.5\end{array}$ & $\begin{array}{c}\mathrm{n}_{1}=11 \\
2.3 \\
0.5-16.1\end{array}$ & $\begin{array}{c}\mathrm{n}_{1}=27 \\
1.5 \\
0.0-45.4\end{array}$ & $\begin{array}{c}\mathrm{n}_{1}=20 \\
6.05 \\
0.4-66.7\end{array}$ & $\begin{array}{c}\mathrm{n}_{1}=17 \\
6.3 \\
0.5-14.6\end{array}$ & $\begin{array}{l}\text { b-f } P<0.001^{*} \\
\text { a\&f } P<0.02^{*} \\
\text { b\&f } P<0.04^{*} \\
\text { c\&d } P<0.003^{*} \\
\text { c\&f } P<0.002^{*} \\
\text { d\&e } P<0.005^{*} \\
\text { e\&f } P<0.002^{*}\end{array}$ & \\
\hline $\begin{array}{l}\text { slL-6R(ng/ml) } \\
\text { Median } \\
\text { Range }\end{array}$ & $\begin{array}{c}\mathrm{n}_{1}=63 \\
53.18 \\
33.8-107.34\end{array}$ & $\begin{array}{c}\mathrm{n}_{1}=7 \\
37.49 \\
35.97-40.63\end{array}$ & $\begin{array}{c}\mathrm{n}_{1}=9 \\
46.69 \\
36.42-107.34\end{array}$ & $\begin{array}{c}\mathrm{n}_{1}=27 \\
62.06 \\
33.80-101.67\end{array}$ & $\begin{array}{c}\mathrm{n}_{1}=20 \\
53.26 \\
34.74-103.85\end{array}$ & $\begin{array}{c}\mathrm{n}_{1}=17 \\
41.19 \\
23.73-67.92\end{array}$ & $\begin{array}{c}\text { b-f } P<0.001^{*} \\
\text { a\&f } \\
\text { b\&d } P<0.001^{*} \\
\text { b\&e } P<0.001^{*} \\
\text { c\&e } P<0.001^{*} \\
\text { c\&f } P<0.001^{*} \\
\text { d\&e } P<0.001^{*} \\
\text { d\&f } P<0.001^{*} \\
\text { e\&f } P<0.002^{*}\end{array}$ & $P<0.004^{*}$ \\
\hline $\begin{array}{l}\text { OSM }(\mathrm{pg} / \mathrm{ml}) \\
\text { Median } \\
\text { Range }\end{array}$ & $\begin{array}{c}\mathrm{n}_{1}=37 \\
0.45 \\
0.0-22.50\end{array}$ & $\begin{array}{c}\mathrm{n}_{1}=2 \\
0.0 \\
0.0-1.2\end{array}$ & $\begin{array}{c}\mathrm{n}_{1}=4 \\
0.0 \\
0.0-10.7\end{array}$ & $\begin{array}{c}\mathrm{n}_{1}=20 \\
1.2 \\
0.0-12.8\end{array}$ & $\begin{array}{c}\mathrm{n}_{1}=11 \\
0.15 \\
0.0-22.5\end{array}$ & $\begin{array}{c}\mathrm{n}_{1}=1 \\
0.0 \\
0.0-1.1\end{array}$ & $\begin{array}{l}\text { b-f } P<0.001^{*} \\
\text { a\&f } P<0.002^{*} \\
\text { c\&f } P<0.001^{*} \\
\text { d\&f } P<0.03^{*} \\
\text { e\&f N.S. }\end{array}$ & $\begin{array}{c}- \\
P<0.001^{*} \\
\text { N.S. } \\
P<0.001^{*} \\
P<0.01^{*}\end{array}$ \\
\hline $\begin{array}{l}\text { sgp130(pg/ml) } \\
\text { Median } \\
\text { Range }\end{array}$ & $\begin{array}{c}\mathrm{n}_{1}=63 \\
460 \\
310-970\end{array}$ & $\begin{array}{c}\mathrm{n}_{1}=7 \\
490 \\
330-550\end{array}$ & $\begin{array}{c}\mathrm{n}_{1}=9 \\
430 \\
350-970\end{array}$ & $\begin{array}{c}\mathrm{n}_{1}=27 \\
440 \\
310-740\end{array}$ & $\begin{array}{c}\mathrm{n}_{1}=20 \\
495 \\
340-730\end{array}$ & $\begin{array}{c}\mathrm{n}_{1}=17 \\
420 \\
310-710\end{array}$ & $\begin{array}{l}b-f \text { N.S. } \\
\text { a\&f N.S. }\end{array}$ & \\
\hline
\end{tabular}

*Statistically significant difference; N.S., non-significant difference.

Surface immunofenotyping by flow cytometry using the dual color staining technique on the peripheral blood and lor bone marrow was performed in all seven patients with 2-CdA induced CR. Residual disease was demonstrated in three out of these patients. The serum levels of investigated cytokines and soluble receptors were similar in the patients with and without residual disease (data not shown).
In the group of active CLL patients we have also analyzed the relationship between the serum concentration of evaluated cytokines, as well as the soluble receptors and the clinical stage according to Rai (Table 4). The lowest IL-6 concentration was found in the patients with Rai $1 \& 2$ (median $1.5 \mathrm{pg} / \mathrm{ml}$ ) as well as those with Rai 0 (median $2.3 \mathrm{pg} / \mathrm{ml}$ ); and the highest concentration in Rai $3 \& 4$ patients (median $6.05 \mathrm{pg} / \mathrm{ml}$ ).

Table 5. sIL-6R/IL-6 ratio and sgp130/IL-6 ratio in the patients with CLL according to treatment response. Median and range in parentheses.

\begin{tabular}{|c|c|c|c|c|c|c|}
\hline Cytokines and receptors & $\begin{array}{l}\text { Untreated } \\
\text { patients } \\
(n=25) \\
\text { (a) }\end{array}$ & $\begin{array}{c}\text { Patients } \\
\text { with CR } \\
(n=7) \\
\text { (b) }\end{array}$ & $\begin{array}{l}\text { Patients } \\
\text { with PR } \\
\text { ( } n=18) \\
\text { (c) }\end{array}$ & $\begin{array}{l}\text { Non- } \\
\text { responded } \\
\text { patients } \\
(n=13) \\
\text { (d) }\end{array}$ & $\begin{array}{l}\text { Control } \\
\text { group } \\
(n=17) \\
(\mathrm{e})\end{array}$ & $\begin{array}{l}\text { Statistically } \\
\text { significant } \\
\text { comparisons }\end{array}$ \\
\hline $\begin{array}{l}\text { slL-6R/IL-6 } \\
\text { Median } \\
\text { Range }\end{array}$ & $\begin{array}{c}\mathrm{n}_{1}=25 \\
22531 \\
630-76556\end{array}$ & $\begin{array}{c}\mathrm{n}_{1}=7 \\
25694 \\
14619-37492\end{array}$ & $\begin{array}{c}\mathrm{n}_{1}=17 \\
219534 \\
1724-113640\end{array}$ & $\begin{array}{c}\mathrm{n}_{1}=13 \\
26510 \\
2974-107390\end{array}$ & $\begin{array}{c}\mathrm{n}_{1}=17 \\
8209 \\
4234-85816\end{array}$ & $\begin{array}{c}\text { a-e } P<0.03^{*} \\
\text { a\&e } P<0.02^{*} \\
\text { b\&e } P<0.002^{*} \\
\text { d\&e } P<0.007^{*}\end{array}$ \\
\hline $\begin{array}{l}\text { sgp130/IL-6 } \\
\text { Median } \\
\text { Range }\end{array}$ & $\begin{array}{c}\mathrm{n}_{1}=25 \\
207 \\
8.8-600\end{array}$ & $\begin{array}{c}\mathrm{n}_{1}=7 \\
250 \\
179.0-540\end{array}$ & $\begin{array}{c}\mathrm{n}_{1}=17 \\
143 \\
15.9-1675\end{array}$ & $\begin{array}{c}\mathrm{n}_{1}=13 \\
179 \\
9.9-850\end{array}$ & $\begin{array}{c}\mathrm{n}_{1}=17 \\
89 \\
28.8-1160\end{array}$ & $\begin{array}{c}\text { b-e N.S. } \\
\text { b-e } P<0.003^{*} \\
\text { d-e } P<0.007^{*}\end{array}$ \\
\hline
\end{tabular}

*Statistically significant difference; $n=$ number of investigated patients; $n_{1}=$ number of individuals with detectable cytokines; N.S., nonsignificant difference. 


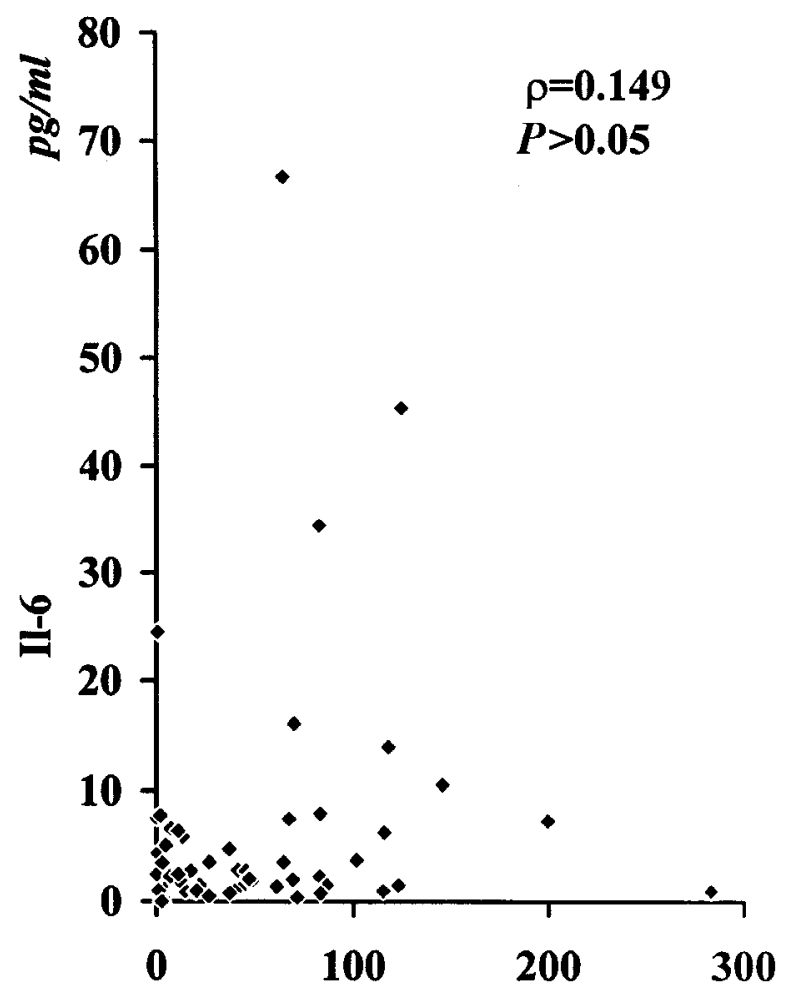

Lymphocvtes $\times 10^{9} / 1$

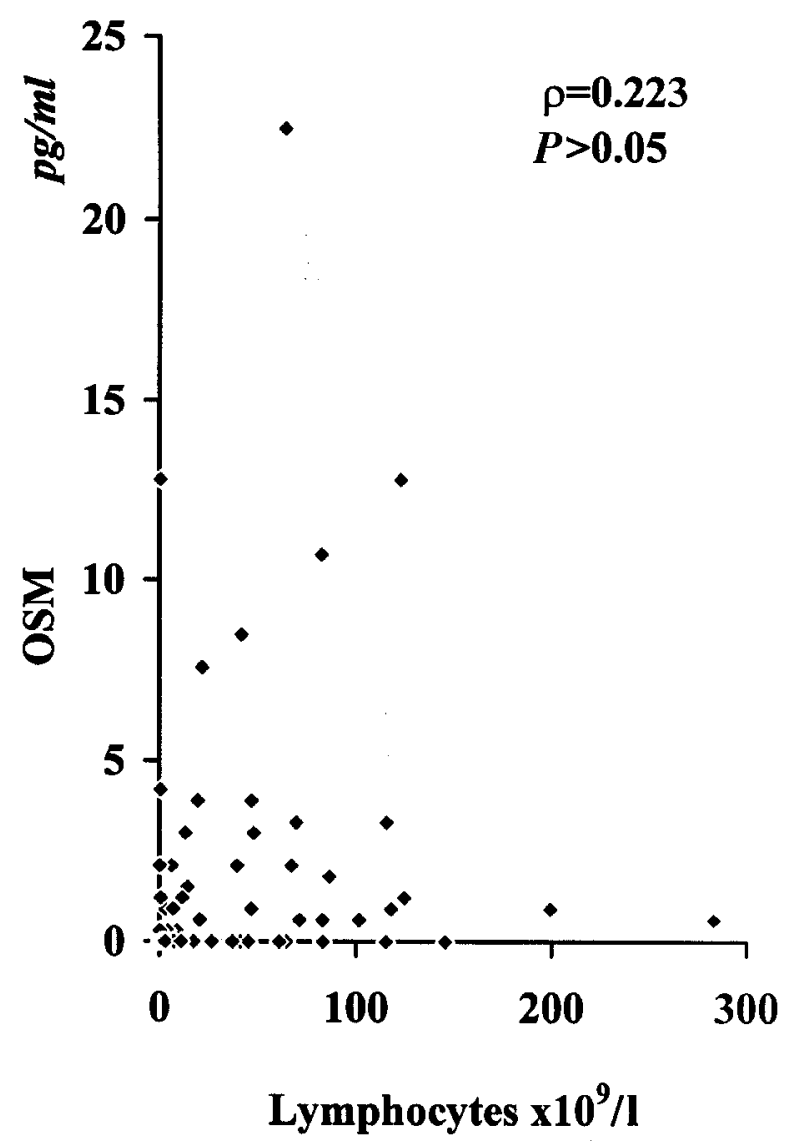

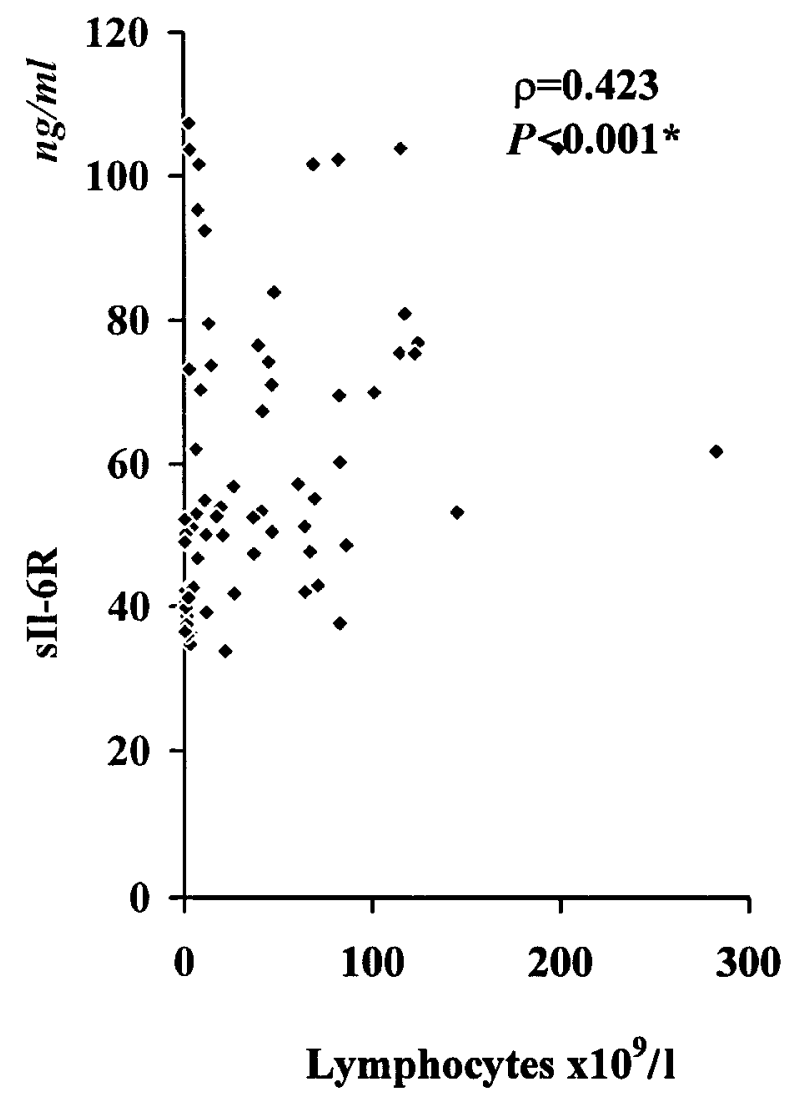

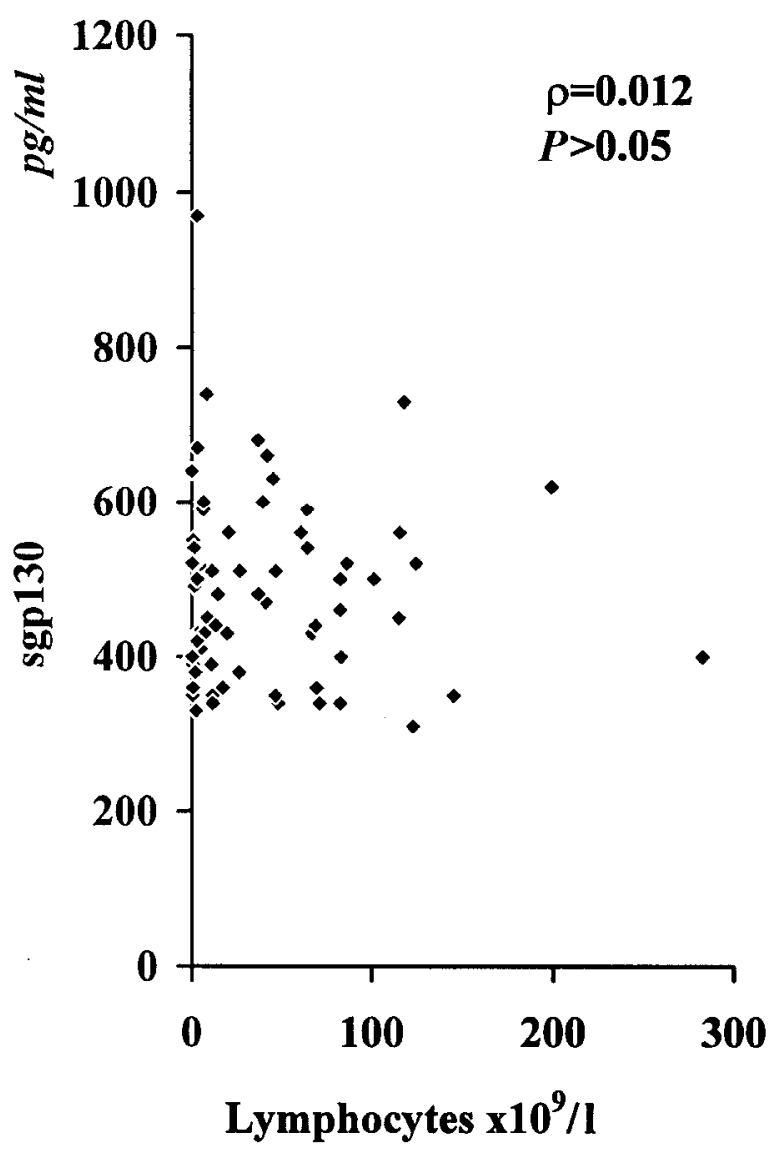

FIG. 1. Correlation between the serum levels of IL-6, OSM, sIL-6R and sgp130 with the number of lymphocytes in the peripheral blood of CLL patients. 

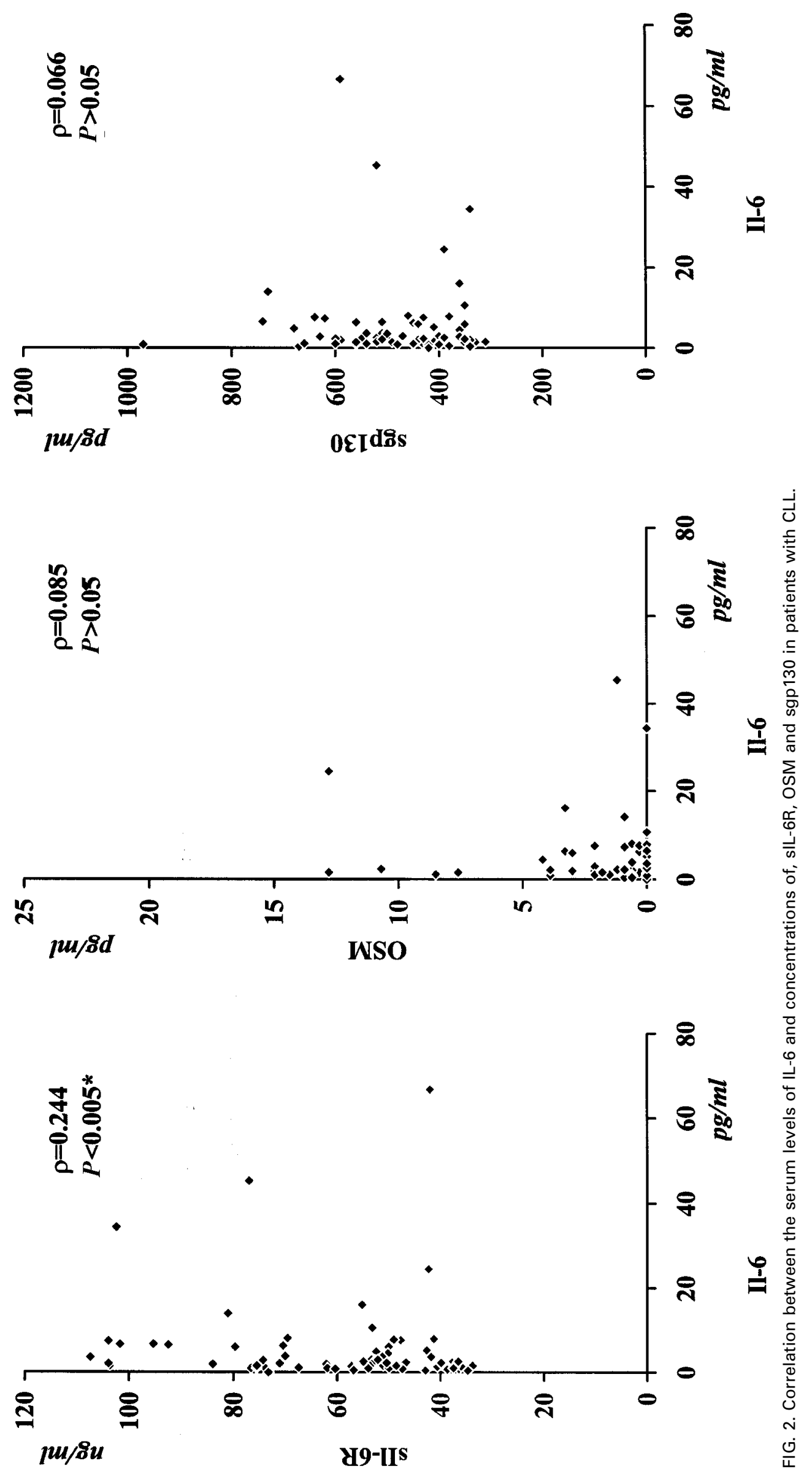
The OSM serum level was higher in the patients with Rai 0 and with Rai $1 \& 2$, when compared to the normal controls $(P<0.001$ and $P<0.03$, respectively). Although the serum concentration of this cytokine in the patients with Rai $3 \& 4$ was not significantly higher, we observed that it was detectable more often in this group, when compared with the controls.

However, the sIL-6R concentration was highest in the patients with advanced Rai stage $1 \& 2$ (median $62.06 \mathrm{ng} / \mathrm{ml}$ ) and 384 (median $53.26 \mathrm{ng} / \mathrm{ml}$ ) and lowest in patients with Rai O (median $46.69 \mathrm{ng} / \mathrm{ml}$ ).

No difference between the gp130 level and clinical stage of the patients was observed.

The calculation of the sIL-6R to IL-6 ratio, as well as sgp130 to IL-6 ratio in the CLL patients and the healthy controls, are presented in Table 5. The sIL6R/IL-6 ratio was significantly higher in the treated patients (median 23040.0) when compared to untreated (median 22530.6) CLL patients $(P<0.0006)$. Moreover, it was also higher in both groups than in the normal individuals (median 8209.7; $P<0.0006$ and $P<0.02$, respectively). The highest ratio was observed in patients who did not respond to 2-CdA treatment (median 26510.0).

We have also found a significantly higher sgp 130/IL6 ratio in patients treated with\$ 2-CdA (median 208.0), when compared with untreated CLL patients (median 206.7; $P<0.01$ ).

The relationship between the serum concentration of evaluated cytokines as well as the soluble receptors and lymphocytes count are show $\mathrm{n}$ in Fig. 1. We have only found a significant positive correlation between the levels of sIL-6R and lymphocytes count in CLL patients $(=0.423 ; P<0.001)$. We have also analyzed the relationship between serum levels of IL-6 with both OSM and the soluble receptors (Fig. 2). The only significant correlation was observed between IL-6 and sIL-6 levels in CLL patients $(\rho=0.244 ; P<0.005)$.

\section{Discussion}

The role of cytokines in the pathogenesis and the clinical course and the monitoring of neoplasmatic diseases has been intensively investigated for the last several years. It seems that the most important cytokines, which play a key role in the pathogenesis of CLL, are IL-2, IL-4 and TNF $\alpha .{ }^{29-32}$ The results of some studies also indicate that IL-6 may play a role in the pathomechanism of CLL. ${ }^{9,12}$ Other cytokines belonging to the IL-6 family have not been yet investigated in CLL. In our study the concentration of three cytokines belonging to IL-6 family has been measured in the serum of 63 patients with B-CLL who had been previously untreated or who had received 2-CdA as a first line treatment, including seven patients who achieved a CR, and in a control group of 17 healthy volunteers. IL- 6 was measurable in all but one of the B-CLL patients and in all the healthy volunteers. OSM was detectable in $80 \%$ of untreated and in $37.8 \%$ of 2 -CdA treated B-CLL patients, but was measurable only in $5.9 \%$ of the controls. LIF was undetectable in all B-CLL patients, as well as in the control group.

The mean concentration of IL- 6 in the serum of untreated patients with CLL was not significantly different, when compared to healthy controls. It is worth stressing that IL-6 concentration was lower in the treated CLL patients than in the untreated subgroup $(P<0.02)$. We have also show $n$ that IL-6 was at its lowest concentration in patients in a CR upon 2-CdA (median $1.4 \mathrm{pg} / \mathrm{ml}$ ), median in a PR (median $2.65 \mathrm{pg} / \mathrm{ml}$ ), and at its highest level in non-responding patients (median $2.8 \mathrm{pg} / \mathrm{ml}$ ). The results of other studies on IL-6 in CLL have reported earlier generally agreed with our observations. ${ }^{33,34}$ Callea et al. ${ }^{34}$ showed that the serum concentration of IL-6 is statistically higher in patients with advanced or progressive stage of disease in comparison with smouldering B-CLL. Nevertheless, there was no statistically significant difference in IL-6 concentration between B-CLL patients and healthy controls. However, Auguilar-Santelises et al. ${ }^{33}$ showed that in patients with monoclonal lymphocytosis of undete rmined significance (MLUS) IL-6 concentration was twice as high as in healthy controls; but in B-CLL patients with stable as well as with in progressive disease the concentration of this cytokine was similar to the control group.

The influence of treatment of cytokines levels in CLL has not been, as yet, intensively studied. Our observations indicate that IL-6 level was higher in the patients with more advanced Rai stages and at its lowest in patients with 2-CdA induced remission. It is generally know $\mathrm{n}$ that 2 -CdA exerts a strong lymphocytolytic effect against leukemic B lymphocytes, which is not selective. This agent causes a long-lasting suppression of T CD4 + lymphocytes and monocytes which produce IL-6, in a similar way to leukemic B lymphocytes. ${ }^{35-37}$ It is supposed that the decrease of this cytokine in the serum of CLL patients upon 2-CdA treatment, particularly in those achieving a CR, even below normal limits, may be explained by the 2-CdAinduced cytolytic effect on various cells producing IL6, including normal and leukemic lymphocytes. Dysregulation of the secretion of IL-6 and other cytokines was reported by Jewell et al..$^{38}$ in B-CLL patients treated with INF- $\alpha$.

Until now, LIF and OSM have not been widely investigated in patients with CLL. Loregot et al. ${ }^{39}$ measured LIF concentration in the serum of patients with various lymphoid malignancies and showed that its concentration was increased in Hodgkin's lymphoma (HL) and in non-Hodgkin's lymphoma (NHL), but in CLL and in healthy controls it remained low. In our study LIF concentration, measured with commercially available kits utilizing the ELISA method, was 
undetectable in CLL patients and in healthy controls. It should be emphasized that similar results were earlier obtained in multiple myeloma, ${ }^{28}$ systemic lupus erythematodes ${ }^{27}$ and rheumatoid arthritis. ${ }^{22}$ In contrast, OSM was detectable in a majority (80\%) of untreated patients with CLL and in only $37.8 \%$ of 2-CdA-treated patients, as well as in only one (5.9\%) healthy control. Moreover, the concentration of this cytokine was significantly higher in untreated patients (median $1.8 \mathrm{pg} / \mathrm{ml}$ ) than in 2-CdA treated patients (median $0.0 \mathrm{pg} / \mathrm{ml}, P<0.05$ ), or than in healthy subjects (median $0.0 ; P<0.001$ ). The lowest values were noted in patients achieving a CR. Similar results were reported earlier in multiple myeloma, where the OSM concentration was statistically higher in progressive disease than in the control group. ${ }^{28}$ These observations are concomitant with those made by Koskela et al..$^{40}$ who detected OSM in $20 \%$ of patients with multiple myeloma. Our results indicate that OSM, like IL-6, may have a significance in the pathogenesis of CLL and may be useful for the monitoring of the clinical course and effectiveness of therapy in lymphoid malignancies.

Soluble IL-6 receptors (sIL-6R and sgp 130) are detectable in the serum and other body fluids in healthy controls and in various pathological conditions. ${ }^{17,20,22}$ sIL-6R has the agonist properties because it is able to bind IL-6 with an affinity almost like that of membrane IL-6R. Moreover, Il-6/sIL-6R complex is able to bind and activate the gp 130 transducer chain. In our study the highest sIL-6R level was observed in the serum of untreated CLL patients, and the lowest values were noted in healthy controls and in CLL patients who entered a CR (Table 3). Lavabre-Bertrand et $a l^{20}$ also reported a significantly higher sIL-6R concentration in the serum of patients suffering from various lymphoid malignancies, including CLL. They showed that the sIL-6R concentration was higher in more advanced stages of disease and suggested its correlation with tumor cell mass. However, in contrast to our observations, they did not show the influence of therapy on the concentration of this soluble receptor. This discrepancy may be explained by the fact that their patients were treated with the chlorambucil or $\mathrm{CHOP}$ schedule and did not receive purine analogs; which may exert a more selective effect on the lymphoreticular system, resulting in more complex relationship between the cytokines and their soluble receptors. It is also known that sIL6R may be generated by the shedding of membrane IL-6R, as well as by the translation of an alternatively spliced RNA. ${ }^{41,42}$ The significant positive correlation between the sIL-6R levels and the number of lymphocytes confirmes the observation made by LavabreBertrand et al. ${ }^{20}$ that leukemic B lymphocytes are released sIL-6R mainly via shedding.

gp130 plays a key role in signal transmission for all the cytokines of IL-6 family (Peters et al. ${ }^{18}$ ). gp130
mRNA is ubiquitously expressed in almost all the examined organs, including the spleen, liver, lung, brain and heart. ${ }^{43}$ In contrast to sIL-6R, the soluble form of gp130 shows antagonist properties. Plasma sgp 130 has been show $n$ to bind circulating IL-6/sIL-6R complex and in this way to prevent cells expressing membrane gp130 from being activated. ${ }^{17}$ To our knowledge sgp 130 concentration in the serum of patients with lymphoid neoplasmas has not been investigated as yet. The concentration of sgp $130 \mathrm{w}$ as similar in the control group and in the CLL patients, as well as in untreated and 2-CdA treated patients. The results of our studies suggest that dysregulation of this protective mechanism may be involved in the pathogenesis of CLL. We can also state that this receptor plays a minor role as an indicator of the tumor mass or a marker of the disease advancement and therapeutic efficacy than sIL-6R, because its concentrations in the serum of CLL patients before and after treatment and in healthy controls do not differ statistically. The differences in observations concerning these two soluble receptors are difficult to interpret and the quantitative analysis of the density of these receptors on the membrane of leukemic cells may provide important information for the better understanding of the mechanism of their proteolytic cleavage in the soluble form.

In conclusion, we have showed that serum concentration of IL-6 is decreased, but OSM and sIL-6R are increased in B-CLL patients in comparison with healthy controls and correlates with the tumor mass and clinical stage of disease. Moreover, in patients achieving a CR upon 2-CdA the level of these cytokines is similar to that in the control group, and in case of IL-6 it is even lower. The serum concentration of sgp130 does not differ significantly between CLL patients and healthy subjects, so its measurement has no practical value in the monitoring of the disease activity and the efficacy of therapy.

ACKNOWLEDGEMENTS: This work has been supported in part by a grant from the Medical University of Lódź, No 502-11-499(124). We thank Ms Jolanta Fryczak for her invaluable technical assistance and Ms Elúbieta Dziankowska-Stachowiak for performing of the statistical analysis of the data.

\section{References}

1. O'Brien S, del Giglio A, Ke ating M. Advances in the biology and treatment of B-cell chronic lymphocytic leukemia. Blood 1995: 85: 307-18.

2. Rozman C, Montserrat E. Chronic lymphocytic leukemia. N Engl J M 1995: 333: 1052-7.

3. Trentin L, Zambello R, Agostini C et al. Expression and regulation of tumor necrosis factor, interleukin-2 and hematopoietic grow th factor receptors in B-cell chronic lymphocytic leukemia. Blood 1994: 84: 4249-56.

4. Touw I, Dorssers L, Lowenberg B. The proliferative response of B-cell chronic lymphocytic leukemia to interleukin-2: functional characterization of the interleukin-2 membrane receptors. Blood 1987: 69: $1667-73$.

5. Trentin L, Zambello R, AgostiniC et al. Expression and functional role of tumor necrosis factor receptors on leukemic cells from patients with type B chronic lymphoproliferative disorders. Blood 1993: 81: 752-8. 
6. Jurlander J, Lai CF, Tan J et al. Characterization of interleukin-10 receptor expression on B-cell chronic lymphocytic leukemia cells. Blood 1997: 89: 4146-52.

7. Rambaldi A, Bettoni S, Rossi V et al. Transcriptional and posteranscriptional regulation of IL-1 beta, IL-6 and TNF alpha genes in chronic lymphocytic leukemia. Br J Haematol 1993: 83: 204-11.

8. Jansen JH, Wientjens GJ, Willemze R, Kluin-Nelemans JC. Production of tumor necrosis factor alpha by normal and malignant B lymphocytes in response to interferon-alpha, interferon gamma and interleukin 4 . Leukemia 1992: 6: 116-19.

9. Emilie D, Leger-Ravet MB, Devergne O et al. Intratumoral production of IL-6 in B-cell chronic lymphocytic leukemia and B lymphomas. Leuk Lymph 1993: 11: 411-17.

10. Zhang XG, Klein B, Bataille R. Interleukin 6 is a potent myeloma-cell grow th factor in patients with aggressive multiple myeloma. Blood 1989: 74: 11-13.

11. Van-Kooten C, Rensink I, Aarden L, van Oers R. Effect of IL 4 and IL-6 on the proliferation and differentation of B-chronic lymphocytic leukemia cells. Leukemia 1993: 7: 618-24.

12. Aderka D, Maor Y, Novick D et al. Interleukin-6 inhibits the proliferation of B-chronic lymphocytic leukemia cells that is induced by tumor necrosis factor alpha or beta. Blood 1993: 81: 2076-84.

13. Kishimoto T, Akira S, Narazaki M, Taga T. In terle ukin-6 family of cytokines and gp 130. Blood 1995: 86: 1243-54.

14. Hawley RG. Hematopathology of interle ukin-6 type cytokines. Stem Cells (Dayt) 1994: 12: (suppl 1), 155-71.

15. Robinson RC, Grey LM, Staunton D et al. The crystal structure and biological function of leukemia inhibitory factor: implication for receptor binding. Cell 1994: 77: 1101-16.

16. Wang XJ, Taga T, Yoshida K, Saito M, Kishimoto T, Kikutani H. gp 130 the cytokine common signal-transducer of interleukin-6 cytokine family, is downregulated in T cells in vivo by interleukin-6. Blood 1998: 91: 3308-14.

17. Yasukawa K, Futatsugi K, Saito T et al. Association of recombinant soluble IL-6 signal transducer gp 130 with a complex of IL-6 and soluble IL-6 receptor and establishment of an ELISA for soluble gp 130. Im m unol Letters 1992: 31: 123-30.

18. Peters M, Müller AM, Rose-John S. Interleukin-6 and soluble interleukin-6 receptor. Direct stimulation of gp 130 and hematopoiesis. Blood 1998: 92: 3495-504.

19. Narazaki M, Yasukawa K, Saito T et al. Soluble forms of the interleukin-6 signal-transducing receptor component gp 130 in human serum possessing a potential to inhibit signals through membrane anchored gp 130. Blood 1993: 82: 120-6.

20. Lavabre-Bertrand T, Ex brayat C, Liautard J et al. Detection of membrane and soluble interleukin-6 receptor in lymphoid malignancies. $\mathrm{Br} J$ Haematol 1995: 91: 871-7.

21. Heaney M, Golde DW. Soluble cytokine receptors. Blood 1996: 87: 847-57.

22. Robak T, Gladalska A, Stepień H, Robak E. Serum levels of interleukin-6 type cytokines and soluble interleukin-6 receptor in patients with rhe umatoid arthritis. Mediat Inflamm 1998: 7: 347-53

23. Cheson BD, Bennett JM, Grever M et al. National Cancer Institute Sponsored Working Group guidelines for chronic lymphocytic leukemia: revised guidelines for diagnosis and treatment. Blood 1996: 87: 4990-7.

24. Robak T, Błasińska-Morawiec M, Błoński JZ et al. The effect of 2-h infusion of 2-chlorodeoxyadenosine (cladribine) with prednisone in previously untreated B-cell chronic lymphocytic leukae mia. Eur J Cancer 1997: 33: 2347-51.

25. Rai KR, Savitsky A, Cronkite EP, Chanana AD, Levy RN, Pasternack BS. Clinical staging of chronic lymphocytic leukemia. Blood 1975: 46: 219-34.
26. Brugiatelli M, Claisse JF, Lenormand B et al. Long term clinical outcome of B-cell chronic lymphocytic leukaemia patients in clinical remission phase evaluated at phenotypic level. Br J Haematol 1997: 97: 113-18.

27. Robak E, Sysa-Jedrzejowska A, Stepień H, Robak T. Circulating interleukin-6 type cytokines in patients with systemic lupus erythematosus. Eur Cytokine Netw, 1997a: 8: 281-6.

28. Wierzbowska A, Urbańska-Ryś H, Robak T. Circulating inte rleukin-6 type cytokines and soluble interleukin-6 receptor in patients with multiple myeloma. Br J Haem at 1999: 105: 412-19.

29. Cordingley FT, Bianchi A, Hoffbrand AV et al. Tumour necrosis factor as an autocrine tumour growth factor for chronic B-cell malignancies. Lancet 1988: 1: 969-71.

30. Mainou-Fowler T, Copplestone, JA, Prentice AG. Effect of interleukins on the proliferation and survival of B-chronic lymphocytic leukemia cell (B-CLL). J Clin Pathol 1995: 48: 482-7.

31. Huang RW, Tsuda H, Takatsuki K. Interle ukin 2 prevents programmed cell death in chronic lymphocytic leukaemia cells. Int J Hematol 1993: 58: $83-92$.

32. Mainou-Fowler T, Prentice AG. Modulation of apoptosis with cytokines in B-cell chronic lymphocytic leukaemia. Leuk Lymph 1996: 21: 369-77.

33. Auguilar-Santelises M, Loftenius A, Lungh C et al. Serum levels of helper factors (IL-1 $\alpha$, IL-1 $\beta$ and IL-6), T-cell products (CD4 and sCD8) sIL-2R and $\beta_{2}$-microglobulin in patients with B-CLL and B lymphocytosis. Leuk Res 1992: 16: 607-13.

34. Callea V, Mo rabito F, Luise F et al. Clinical significance of sIL-2R, sCD23, sICAM-1, IL-6 and sCD14 serum levels in B-cell chronic lymphocytic leukemia. Haem atologica 1996: 81: 310-15.

35. Lahat N, Aghai E, Maroun, B, Kinarty, A, Quitt, M., Froom P. Increased spontaneous secretion of IL-6 from B cells of patients with chronic lymphatic leukaemia (B-CLL) and autoimmunity. Clin Exp Immunol 1991: 85: 302-6.

36. Seymour JF, Kurzrock R, Freireich EJ, Estey EH. 2-Chlorodeoxyadenosine induces durable remission and prolonged suppression of $\mathrm{CD}^{+}$lymphocyte counts in patients with hairy cell leukemia. Blood 1994: 83: 2906-11.

37. Carrera CJ, Terai C, Lotz M, Curd JG, Piro LD, Bentler E, Carson DA. Potent toxicity of 2-chlorodeoxyadenosine tow ard human monocytes in vitro and in vivo. J Clin Invest 1990: 86: 1480-8.

38. Jew ell AP, Worman CP, Giles FJ, Goldstone A. H serum levels of TNF, IL-6 and $s \mathrm{CD} 23$ correlate $w$ ith changes in lymphocyte count in patients $w$ ith B-cell chronic lymphocytic leukaemia receiving interferon alpha the rapy. Leuk Lymph 1997: 24: 327-33.

39. Lorgeot V, Praloran V, Turiure P, Denizot Y. Concentration of serum leukemia inhibitory factor (LIF) in patients with hematologic malignancies (Letter). Leukemia 1997: 11: 311-12.

40. Koskela K, Belliniemi TT, Remes K, Rajamaki A, Pulkki K. Serum oncostatin $\mathrm{M}$ in multiple myeloma: association with prognostic factors. Br J Haem at 1997: 96: 158-60.

41. Müllberg J, Schooltink H, Stoyan T et al. The soluble interleukin 6 receptor is generated by schedding. Eur I Immunol 1993: 23: 473-80.

42. Lust JA, Donovan KA, Kline MP, Greipp PR, Kyle RA, Maihle NJ. Isolation of an mRNA encoding a soluble form of the human interleukin-6 receptor. Cytokine 1992: 4: 96-100.

43. Saito M, Yoshida K, Hibi M, Taga T, Kishimoto T. Molecular cloning of a murine IL-6 receptor associated signal transducer gp 130 and its regulated expression in vivo. J Im munol 1992: 148: 4066-71.

\section{Received 11 October 1999.} accepted 17 November 1999 


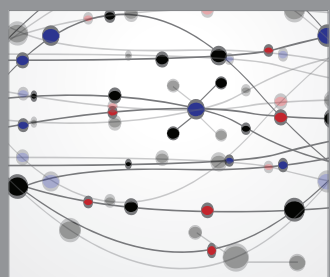

The Scientific World Journal
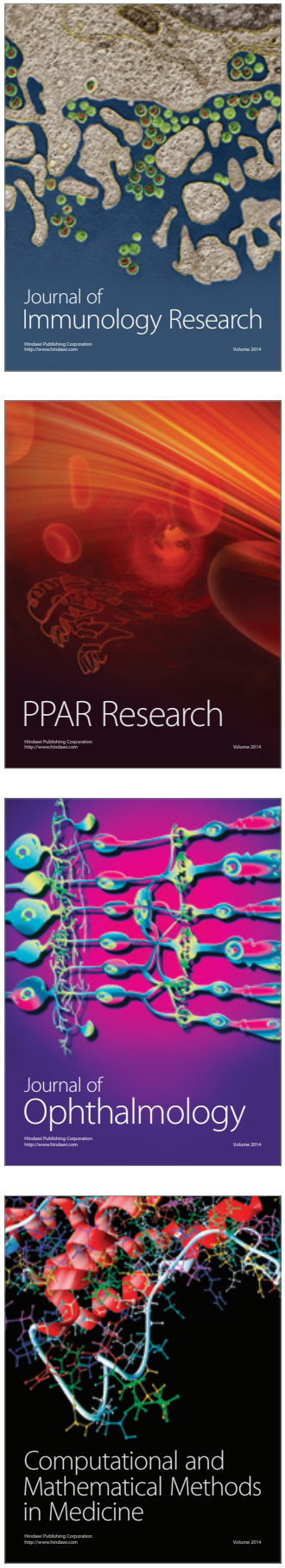

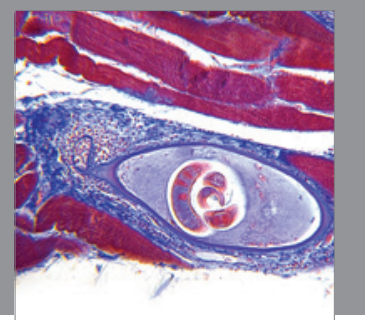

Gastroenterology

Research and Practice
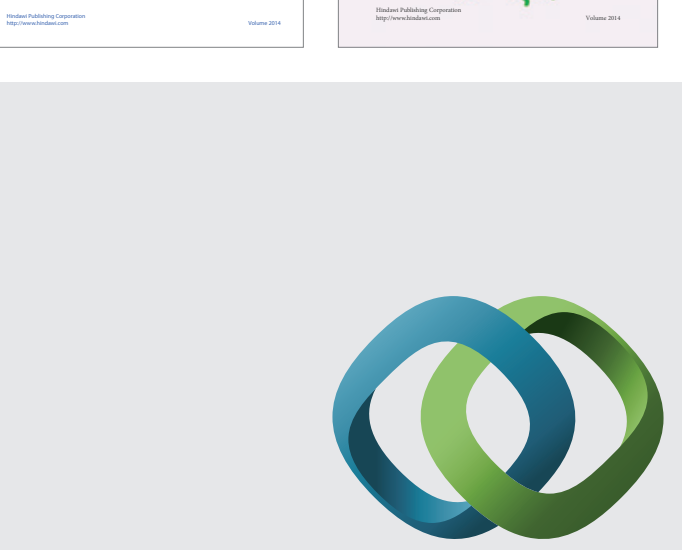

\section{Hindawi}

Submit your manuscripts at

http://www.hindawi.com
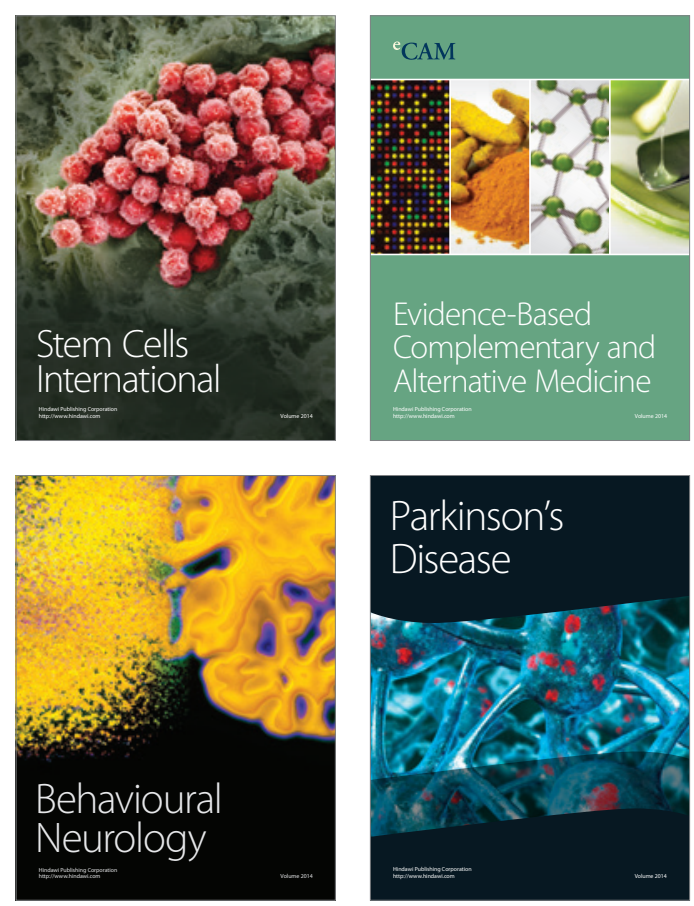

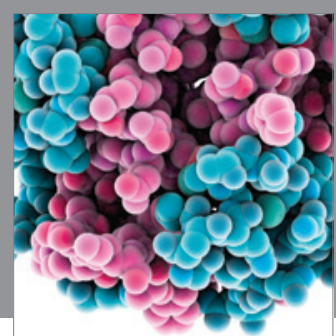

Journal of
Diabetes Research

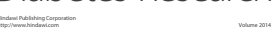

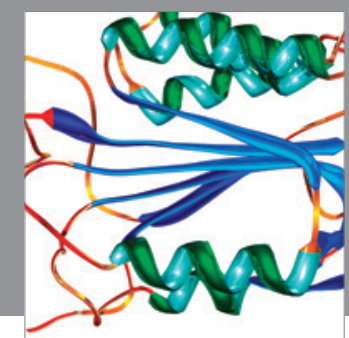

Disease Markers
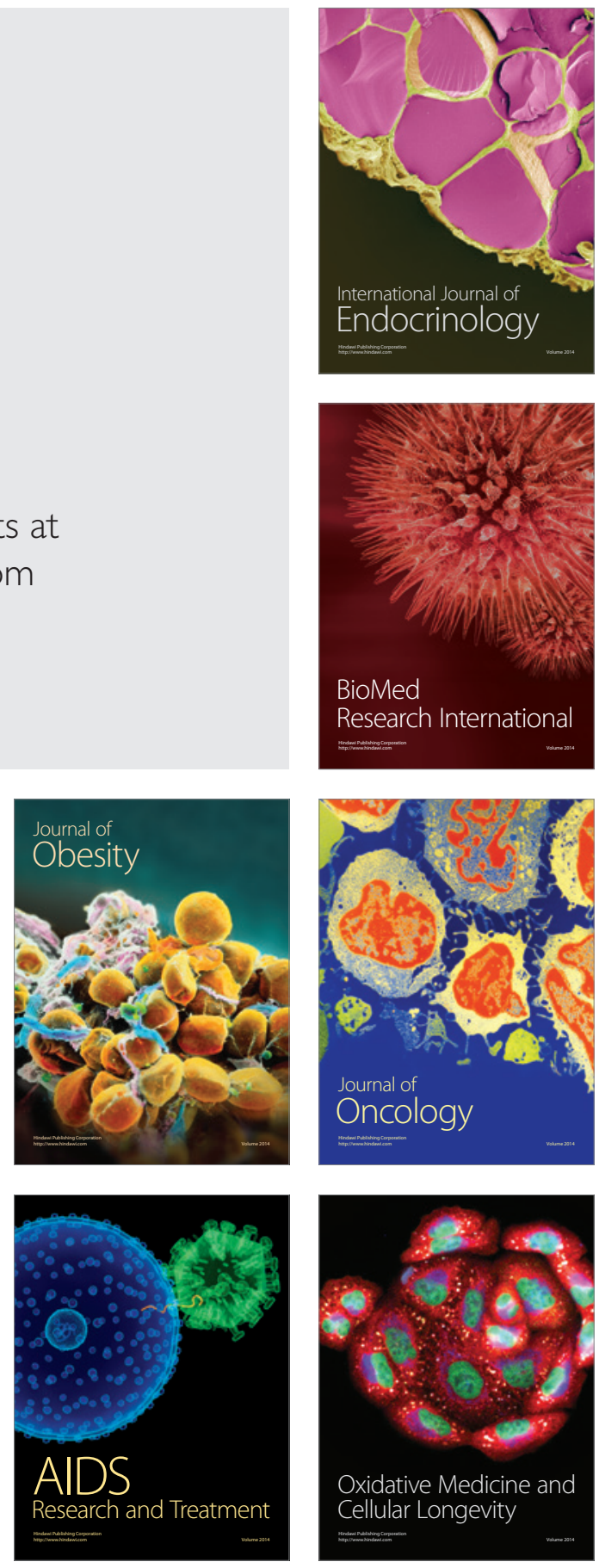